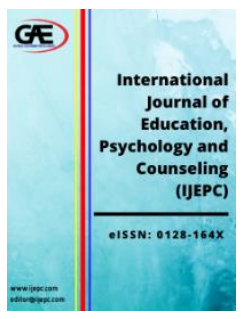

\author{
INTERNATIONAL JOURNAL OF \\ EDUCATION, PSYCHOLOGY \\ AND COUNSELLING \\ (IJEPC) \\ www.ijepc.com
}

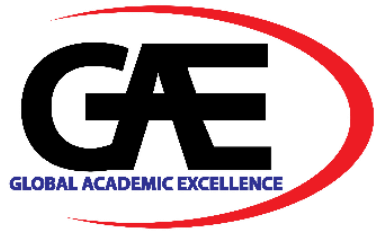

\title{
PERCEPTIONS OF MRSM ENGLISH TEACHERS ON PROFESSIONAL DEVELOPMENT AND THEIR EXPECTATIONS ON IN-SERVICE TRAINING
}

\author{
Faizahani Ab Rahman ${ }^{1 *}$, Nurul Afrahah Hussin ${ }^{2}$, Sutha A/P Sugumaran ${ }^{3}$ \\ 1 School of Education, Universiti Utara Malaysia, Kedah, Malaysia. \\ Email: faizahani@uum.edu.my \\ 2 School of Education, Universiti Utara Malaysia, Kedah, Malaysia. \\ Email: nhus742@aucklanduni.ac.nz \\ 3 School of Education, Universiti Utara Malaysia, Kedah, Malaysia. \\ Email: suthasugumaran@gmail.com \\ * Corresponding Author
}

\section{Article Info:}

Article history:

Received date: 06.06.2021

Revised date: 27.07 .2021

Accepted date: 08.08.2021

Published date: 05.09.2021

\section{To cite this document:}

Ab. Rahman, F., Hussin, N., \& Sugumaran, S. (2021). Perceptions of MRSM Teachers on Professional Development and Their Expectations On In-Service Training. International Journal of Education, Psychology and Counselling, 6 (42), 155-167.

DOI: $10.35631 / \mathrm{IJEPC} .642013$.

This work is licensed under CC BY 4.0

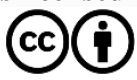

\begin{abstract}
:
This paper looks at the perceptions of MRSM (Majlis Amanah Rakyat or also known as People's Trust Council) English teachers on their current professional development and their expectations on in-service training. As teachers, they are often expected to act as a source of motivation to their students apart from being accountable in providing instructions, knowledge, and skills in their respective academic subjects. However, very often, teachers are not provided with sufficient and appropriate training that would prepare them to be the kind of teacher that they are required and expected to be. This prompts this study that determines whether the in-service training provided is sufficient and aptly to help the teachers produce academically excellent students. This case study used a qualitative approach with purposive sampling of seven English teachers at Maktab Rendah Sains MARA, Beseri in Perlis with teaching experiences between 10 to 30 years. Semi-structured interviews and focus group methods were used to answer the research question which dwells on the MRSM English teachers' expectations of professional development teacher training of their students' achievement. The findings of the study revealed that teachers expect to have more professional development in terms of pedagogy, proficiency level, technology integration, and stress management. They also believe that improvement in professional development can positively affect their students' achievement as teaching and learning processes can be done more effectively. It is therefore recommended that MARA should highlight its current in-service training and development policy to be consistent with the needs of teachers.
\end{abstract}


Professional Development, In-Service Teacher Training, Students' Performance, Pedagogy, Technology Integration, Stress Management

\section{Introduction}

Teachers are one of the many crucial factors that contribute to students' academic achievement. Numerous studies have linked teacher factors to school's success, positive and healthy school climate, students' motivation and students' achievement, amongst others (Lortie, 2020; Ismail, Rahman, and Yaacob, 2020; McEown, and Takeuchi, 2014; Tsegay, and Ashraf, 2015). Due to them being highly linked to many schools' achievement, it is imperative that teachers be equipped with updated content knowledge, skills and competencies and they be continuously encouraged to be passionate and committed in their teaching to ensure that teaching and learning processes occur effectively. The performance of teachers is vital as it can affect on the learners' cognitive and emotional development, and in turn help students to perform academically better at schools.

The Malaysian Ministry of Education and its agencies such as English Language Teaching Centre (ELTC), which is responsible for the training, re-training and upskilling of Malaysian English language teachers to accomplish its vision and mission which is to enhance, build, develop and sustain the quality of English language education. Through various initiatives and programmes such as Highly Immersive Programme (HIP), the Professional Upskilling of English Language Teachers (Pro-ELT), the English Language Enhancement in Schools Programme (PPKBIS) and the Dual Language Programme (DLP), ELTC along with the ministry have provided professional development to continuous support to in-service teachers.

Teachers in Malaysia have become the driving force to raise the capacity of knowledge and innovation and nurture the 'first class mentality' among their students. Globalization has forced measures to be taken to ensure that quality education and training to be in par with international best practices. The growing needs and dire expectations from stakeholders and society have demanded that teachers are not to be regarded solely as imparter of knowledge and information, but also in shaping the new generation with values, principles and morale. Thus, the responsibilities of teachers have now expanded beyond classrooms, and this requires them to be retrained.

The need to have higher English proficiency level has become a more pressing matter since English has been widely associated to global's connectivity through education. Although the Ministry of Education and ELTC have promulgated programmes that would elevate Malaysian students' proficiency levels, there is much need to direct changes in many aspects of the teaching and learning processes. This calls for our teachers' training to be made more frequent, relevant and significant. This is needed to equip teachers with adequate content knowledge and teaching skills that could help them in their teaching approach. Pring (2011), for instance, emphasized that curriculum development and professional development are integral and there can be no curriculum development without teacher development.

Teachers' professional development is viewed as the key factor in school that impacts students' achievement and successful reforms in education (Wiliam, 2013a; Had and Rashid, 2019). Teacher education program in terms of teachers training, is an integral part of the education Copyright $\odot$ GLOBAL ACADEMIC EXCELLENCE (M) SDN BHD - All rights reserved 


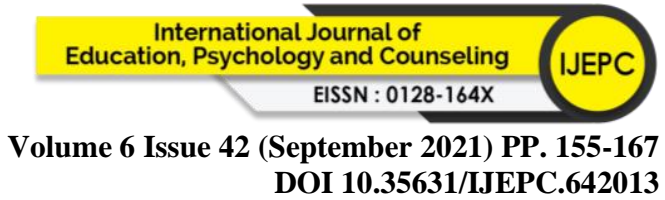

system must be constantly be reviewed and revised to suit the needs to the emerging needs of the nation.

Malaysia's education system is outcome based. As stated in the National Curriculum, this means that by the end of their educational experience, pupils should achieve a certain set of goals as stipulated in the curriculum. To do this, the training programme of English teachers must be updated so that the skills of English teachers in Malaysia could be upgraded and retrained for them to implement the new curriculum. This means, the professional development in terms of teachers' training must be given an utmost attention. Any changes in the curriculum would affect teachers' content knowledge, pedagogy and skills as a whole. It is noticeably worrying that some teachers are having difficulty to cope with the changes, placing them in need to be retrained and to boost their professional development. The new curriculum requires teachers to keep updating their existing teaching strategies and skills to meet the demand of the most recently implemented curriculum. This is essential to ensure the delivery of knowledge can occur effectively in improving students' academic achievement.

Although the changes in education system globally have also impacted on teachers' professional development, where teacher training has now been revised, improved and redesigned to adeptly address global needs and changes, these trainings are scarce and very often, are not offered to many, depriving some of the much-needed training for most. The newly revised teachers training programmes would improve proficiency levels, content knowledge and pedagogical skills of English language teachers, amongst others (MOE, n.d.b. 2013; 2014). While teachers are burdened with increasing and demanding workload, the training provided for them is still unattainable for most teachers, especially those in Maktab Rendah Sains Mara. Kepol (2017), for instance, observed that in many cases, teachers would receive second-hand information of the training content from those attended the training when in-house training was given in the respective schools. Very often, in-service teachers were also left without training for some time and would resort to using their own resources or learning independently through their own teaching experiences, as a result of waiting for the in-house training or their turn to attend the much needed training themselves.

This study accentuates the perceptions of MRSM English language teachers on the current professional development and their expectations of professional development in terms of teachers training as it there are many issues pertaining to insufficient and inadequate trainings given to MRSM teachers. Literature is scarce in the topic, prompting this study to explore on MRSM teachers expectations on professional development (PD) since it is highly linked to students' achievement. It is after all, the purpose of professional development "to develop the knowledge, skills, practices, and these 3 dispositions are needed to help students perform at high levels" (Learning Forward, 2014, p.14). This paper thus sets out to answer this question: What are MRSM English teachers expectations of professional development in terms of teachers training on students' achievement?

\section{Literature Review}

The following literature review will look at the definition of professional development for teachers and professional development of teachers in Malaysia.

\section{Definition of Professional Development}

Day (1999) defines professional development as all natural learning experiences as well as conscious planned activities which benefits the individual teacher, students, school and the Copyright (C) GLOBAL ACADEMIC EXCELLENCE (M) SDN BHD - All rights reserved 


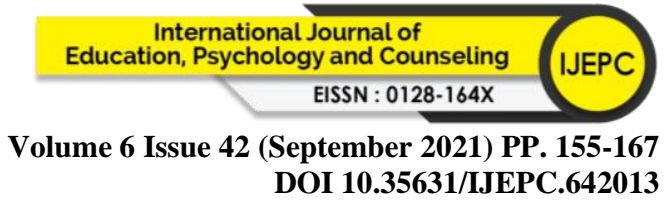

quality of education in classrooms. Here, Day views professional development as any activities that would help the whole school system to achieve quality education that would contribute to students' academic achievement. Thus, quality of education is the goal of professional development of the teachers. "Teacher development is the professional growth a teacher achieves as a result of gaining increased experience and examining his or her teaching systematically" (Glatthorn, 1995, p. 41). This teacher's experience can be further divided into 2 categories, formal and informal in which the former are the regularly planned and scheduled trainings, seminars, workshops or any enriching knowledge, competencies and skills of the teachers, while informal are events such as watching documentaries on profession related subjects, reading journals, policy papers and so on. All of these contribute to the growth of teacher careers and where teachers can develop themselves and allow they grow to be competent and efficient teachers in liaise with Malaysia's education aspiration to produce a keconomy labour market.

In the last few decades, professional development was regarded as short term and one-off training process. Teachers were requested to attend workshops where they can gain information and be trained for any new policies. However, in recent years, professional development goes beyond short term training and workshops, encompassing activities such as pursuing professional qualification, enrolling in planned, structured and more systematic programmes that would not only equip teachers with knowledge and information, but more importantly help to motivate and boost the teachers own personal development and growth to become better educators.

Teachers are also regarded as agents of change in schools and community since they are often provided with the opportunity to review, renew and extend their commitment towards education system. Teachers are expected to keep abreast with the global changes that require revamp, development and of education system that would equip and prepare students with for the outside world. Enhancing teacher quality is a step forward towards creating a successful school and this is highly linked to the quality of initial and continuing teacher education programmes (OECD, 2012). Wiles (2009) stated one crucial aspect of curriculum development is curriculum improvement involving staff development. Professional Development (PD) is a tool that can assist in preparing teachers with the necessary skills, knowledge, and resources and is essential in enhancing classroom instruction to meet the needs of today's learners and ensuring academic success (Guskey, 2002).

\section{Professional Development of Teachers in Malaysia}

Teacher's training education in Malaysia is under the jurisdiction of the Teacher Education Division (TED), a department within the Malaysian Ministry of Education. It oversees, supports and determines the direction of teacher education and training. This TED collaborates with several units under the Ministry of Education to plan and coordinate various programmes that would benefit and improve teaching profession in Malaysia. Some of the objectives are TED are to train teachers of high calibre to fulfil the requirements of all pre-schools, primary, secondary, vocational and technical education within the national educational system and to constantly update and upgrade the knowledge, competency and efficiency of teachers and lecturers in academic and professional areas.

\section{Pre-Service Courses}

In July 2005, all 27 Teacher Training Colleges were upgraded to Institutes of Teacher Education (ITEs). Following this, in the year 2007, the first intake of the 4-year degree-level 


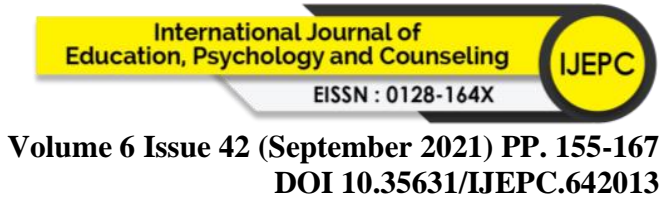

course in which 3725 students were enrolled for the Bachelor of Teaching (PISMP) programme who will be teaching primary schools. Its curriculum is operated on five basic principles namely, to be outcome-based, coherent, spiral and developmental, holistic, as well as practical and contextual. The aim was to achieve specific learning outcomes as required by the Malaysian Qualifying Framework (MQF) in accordance with the 21 st century skills. The PISMP programme not only focuses on the integration of knowledge, but also skills and noble values where students acquire hands-on learning through the transfer of theoretical knowledge to real life situations.

\section{In-Service Courses}

The training programmes in the 2014 MBMMBI Malay acronym MBMMBI (Memartabatkan Bahasa Malaysia dan Memperkukuh Bahasa Inggeris), and its English translation as 'To Uphold Bahasa Malaysia and to Strengthen the English Language' booklet (MOE, 2014), the current training programmes for in-service teachers are traditional and have not gone through many changes. The contents are different but the approach to deliver the training programme has not really changed over the years (Kepol, 2017). Many of the in-service courses are designed to upgrade primary and secondary school teachers' so professional skills and competencies academically and professionally. Apart from that, the courses are placed to allow teachers to keep abreast with the current developments and new practices in the education sector such as the introduction and practice of CEFR, as well as prepare them for the challenges faced by education sector globally. Some of the most commonly organized and conducted courses include:

- The Continuous Professional Development (CPD) for teachers at the institutions of teacher training

- An on-going short term in-service training and development programme (course duration ranges from one to five days)

- An on-going short term in-service training and development programme for teachers teaching critical subjects namely Science, Mathematics, ICT and English

- Special post graduate programmes for teacher trainers namely Masters and PhD level

- Malaysian Trainers Development Programme (14-week course for professional development; these courses are customised to upgrade primary and secondary teachers and there are 20 courses to choose from), and

- Specialist courses for teachers which take approximately one year, offered to primary teachers with three years of experience, emphasizing academic content in ICT.

Although the courses run periodically throughout the years and teachers could request professional training and courses they wish to attend, the seating for these courses are limited and very often, they are taken up by the school's management.

Had and Rashid (2019) mentioned that although digital skills have been recognized as crucial for teachers since they need these to meet the needs and expectations of teaching English in the current time, the training programmes for in-service teachers have not been futile since there are many issues raised regarding the unfriendly system that is caused by data congestion. This will dampen the teachers' efforts in improving their digital skills and competencies.

\section{Methodology}

Since the research question gauges on the MRSM English teachers expectations of professional development in terms of teachers training on students' achievement, where their expectations Copyright $\odot$ GLOBAL ACADEMIC EXCELLENCE (M) SDN BHD - All rights reserved 


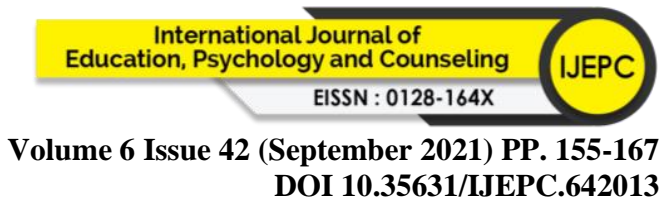

will be looked at from the teachers' perspectives and their understanding of what professional development means to them. In doing so, it will be more appropriate to use qualitative as it allows for the exploration of how people interpret experiences, construct their world, and the value of their experiences to identify emerging themes (Creswell 2009, 2013).

\section{Participants}

Purposive sampling was employed in the study as it provides detailed exploration of issues. The participants in the study consist of seven English teachers in MRSM Beseri with at least 10 years teaching experiences. Although there are a total of twelve English teachers at the school, only seven were approached when a detailed profile was made on the twelve teachers. The seven teachers comprised of different background such as years of age, years of experience teaching qualification and lastly, the number and kinds of training programmes they had attended. The teachers are all Malaysians and from one ethnic group namely Malay. The ages of the teachers varied from middle thirties to early fifties. All of them are female teachers since there is no male teacher in the unit. The teachers were given pseudonym names; Orkid, Melur, Jasmin, Melati, Lili, Rose and Kenanga. As part of ethical consideration, they were briefed beforehand of the study.

\section{Semi-structured Interviews}

The interviews were conducted individually with the purpose to gain detailed information and responses from the teachers regarding their views on teachers' professional development training in terms of lesson development and materials preparation. As reiterated by Braun and Clark (2013), interviews are suited for research that looks in depth the experience of participants and understanding the perception of participants towards a topic or subject. As a qualitative tool, a semi-structured interview was used here and the interviews were on the MRSM teachers' perceptions of current professional development, expectations of professional development, and classroom practices post-professional development. Some of the questions were directed on the types of trainings they had attended and the kinds of training they deem important to for them to attend. The teachers were guided on the types of courses they could be interested and need to attend. Some of the probing questions centred on trainings that are on knowledge on digital tools, teachers' proficiency level, preparing and designing materials and assessments.

The teachers were also asked to recall and describe their thoughts about teachers' training that they have received and their expectations of professional development in terms of teachers training on students' achievement. The interviews accentuated on the types of courses that teachers find important to attend and how they order it according to importance. Teachers were also asked the reasons behind the order to get clearer insight on teachers' view on the more needed courses. Eight semi-structured interview items were included to help the researcher gain detailed information on the current study. The questions developed for the interviews were based on teacher perceptions of current professional development, expectations of professional development, and classroom practices post-professional development.

\section{Data Collection}

Data collection incorporated participant individual face-to-face or online interviews as well as focus group discussions. Participants were also asked to explain how professional development met their needs or could be enhanced. Teachers were asked to include notes about the topics, questions they had, possible solutions to confusion or problems, new insights, and a critical view of their learning. Each interview consisted of three open-ended questions and four semiCopyright (C) GLOBAL ACADEMIC EXCELLENCE (M) SDN BHD - All rights reserved 


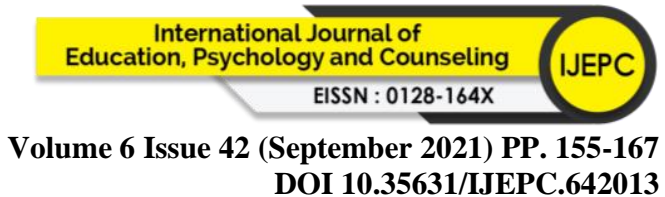

structured questions that pertained to teachers' current perception on their professional development and how would they value the teacher trainings they have received as well as teachers' expectations of professional development in terms of teachers training on students' achievement.

\section{Focus Group Discussions}

This study used focus group as one of its methods to gain in-depth understanding on teachers' current perception on their professional development and how would they value the teacher trainings they have received. There was also a discussion on the teachers' expectations of professional development in terms of teachers training on students' achievement. Most teachers agreed that the most important courses they would like to receive is familiarising oneself with tools. This is to meet the demands of 4.0 revolution in integrating technology in education. Hence, teachers believe the must learn more tools that are appropriate to be used in their PdPc and PdPR (online learning). This current Covid-19 pandemic is also another great issue to be concerned of. The outbreak has changed our education system whereby we are dependent on online learning classes. Teachers are still experimenting to find ways to best deliver the knowledge to their students through virtual learning. For that reasons, all the teachers highlighted familiarising oneself with tools as most needed course for the time being in order to be more creative and competent in conducting online classes.

This was followed by other courses such as materials preparations, specific lesson development training, teachers' language proficiency and stress management. In the group discussion focus group, stress management is seen as the least needed because most the teachers agreed that their roots of stress usually come from their difficulty in coping with their learning tools, preparing materials and developing lesson plan. These courses highlight more on teachers' content knowledge. If these problems can be overcome, it would be easier for them to manage their stress. Sometimes, they also feel stressful when it involves personal matters in terms of marital relationship, financial status etc. Nevertheless, the participant did not accentuate on the factors to be the main problems as they believe they tend to work effectively when they are equipped with sufficient knowledge and skills as an educator.

\section{Data Analysis}

Qualitative data analysis follows several steps that include organizing and preparing data, reading and reflecting on overall meaning, conducting analysis based on method, generating a description of people and identifying themes, representing data, and interpreting the larger meaning of data (Creswell, 2013). Each interview and focus group aligned specifically to the research questions to facilitate data analysis.

The data obtained through both the interviews and focus groups were coded based on numerous emerging themes developed. This allows comparison with other methods to be made on teacher perceptions of current professional development, expectations of professional development, and classroom practices post-professional development. Since the participants are allowed to provide their responses through writing and in person, the researcher will transcribe the recorded data that are carried out in person. The data will be documented by using textprocessing software, Microsoft Word.

Once all of the research interviews and focus group discussions have been transcribed and checked, coding process will be begun. Coding can be defined as "the process of analyzing qualitative text data by taking them apart to see what they yield before putting the data back Copyright (C) GLOBAL ACADEMIC EXCELLENCE (M) SDN BHD - All rights reserved 


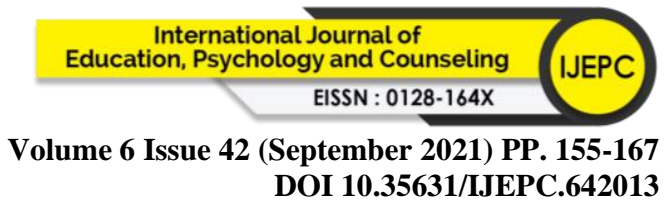

together in a meaningful way" (Creswell, 2015, p. 156). The purpose of coding as mentioned by Creswell (2015) is to make sense of the data as text data are dense and it is such a tedious process to go through them one by one. Hence, coding helps the researchers to do tagging data then taking all the responses given by the participants. For instance, tagging data enables the researcher to select given responses and relate them to the research questions rather than use all the responses unnecessarily. Besides, field notes compiled during an interview and focus group discussions can be a useful complementary source of information to facilitate this process, as the gap in time between an interview, transcribing, and coding can lead to memory bias regarding non-verbal or environmental context issues that may influence interpretation of data.

\section{Findings}

From the analysis of both the interviews and focus group discussions transcriptions, they were 5 professional development trainings that MRSM English language teachers mentioned which were digital skills, English proficiency levels, managing skills/training, stress management and designing assessments.

\section{English Proficiency Levels}

Both Melur and Lili claimed that they are being self-conscious of their proficiency level as compared to their colleagues, they graduated from local universities. They constantly felt that their proficiency levels are being tested and judged by others, including students. Although in recent years, there have been workshops and seminars organized by the State Education Department, nevertheless, they felt that they could be more courses made available to help them improve their proficiency. The laments that are usually heard are teachers are expected to take proficiency tests, but there are no intensive classes made available for them to introduce them to the format and the strategies in answering the questions.

I wish there are some English language courses where we could just be students, for us just to improve our proficiency. This will help with our confidence (Melur).

I constantly think that people judge me and I am not as good as the other English teachers since I graduated from UXX. As you can see, most of the teachers here graduated overseas. Only very few of us were from here (Lili).

There are no recent courses or tests offered to assess teachers' language proficiency, by MARA and its counterpart, with the pretext that these teachers are proficient enough to be chosen to teach at MRSM. According to these teachers, it is important to teachers in order to boost their confidence and self-development as an educator. Teachers' proficiency must be upgraded and improved from time to time to ensure the delivery of knowledge can be done effectively. Both commented that they would like to receive more specific training on lesson development.

I can't remember when was the last time I attended a course outside MRSM . They often ask us if we are ok, and think we are ok. We do not need to take up any courses, just teach and take the MUET, APTIS and CEFR test. (Kenanga).

I want to take some courses to help with my writing as I think I have not done a lot of writing since I started teaching. But.. no course, it is always about how to teach. But that is also like twice a year and because I am a junior, I don't get to go. Always the 


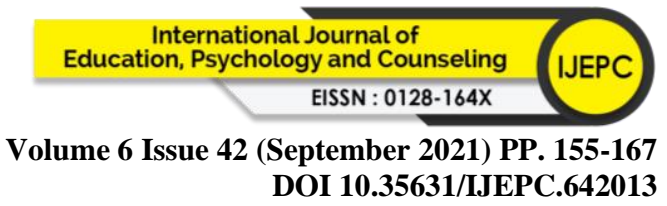

same people or teachers from the other MRSM. I think people have forgotten us and me (Lili).

\section{Managing Skills/Training}

Jasmin, in her interview claimed that the teacher training that she received is inadequate. This is because teachers require to do other jobs apart from teaching such as being a club advisor, sports advisor event coordinator etc. Therefore, teachers must be equipped of management knowledge and event organisation. Most teachers do not receive proper training on how to handle these activities/programs. Some of the courses she has attended to date are related to the integrity of civil servants and the organisation she is working in. This Covid-19 pandemic also affects the courses they receive in terms of safety and health issues to make it relevant to the current circumstance.

I have only 3 years of teaching experience and yet I have been assigned so many roles and responsibilities. Sometimes, I wonder. What is my actual task? Teaching? clubs advisors? secretary to some committee? It seems that we have to learn how to do everything on the job. Not once I have been gone into an induction course or mentoring course that helps the novice teachers how to manage class and other work-related responsibilities (Jasmin).

This is supported by two of her colleagues, Orchid and Kenanga, who also mentioned that due to the pandemic, the demands of delivering online courses along with administrative work have caused exhaustion and fatigue on them, physically and mentally. However, in the past one year or so, the only training made available were focused on developing and designing lessons that are online based.

I wish we have been exposed to some courses on managing multiple roles and tasks as a school teacher in Malaysia. I did not realize that there are some many other tasks that we need to do. Is there a course that exposes us on how to do things that we are expected to do at school (Orchid)?

I have to learn by doing and ask people how to do things. I remember being appointed as the debate teacher the moment I started teaching and I was totally clueless to what I was supposed to do. Now that I have some experience, I still find it difficult when I am assigned new role, like now, it is the treasurer for parents-teachers association (Kenanga).

\section{Digital Skills}

In the focus group discussions, Orchid and Rose asserted that they have not received enough training in terms of familiarising oneself with tools and materials preparation. These skills have been acquired on their own through observations and research. They believed that it would be useful for their professional development if they would have received the training during her pre-service teaching. Orchid also mentioned that these kinds of training would help to reduce her stress level as she would know how to prepare her lesson as expected in a given duration. On the other hand, Rose claimed she was having a hard time when online classes were first implemented. This is so because teachers were not given enough preparation before the ad-hoc implementation due to Covid-19 outbreak. In her comment, she also mentioned the need to go for a proper training in handling digital materials, assessments that are seem to be 


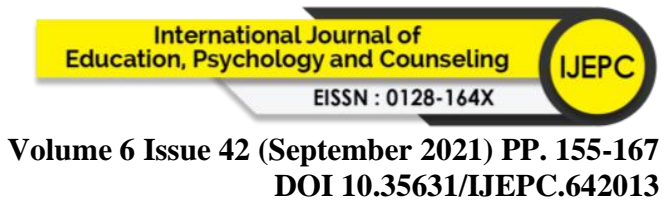

I have heard friends from other schools and they have mentors. Their mentors are wellversed in using technologies, so they get help a lot. Sometimes, they have people from the State Education Department, or they have online seminars where they teach us how to engage students in class, how to prepare for interactive lessons and many more (Orchid).

I am not good with computers. So, online learning was difficult. I had to ask people. I have to watch You tube. In the beginning, to set up the class, I do not know. It was tough. And how to convert materials and assessments online. I think our friends in our schools are more knowledgeable than us. They always seem to be ahead of us. They seem to know what they are doing or how to do it and also where to get help (Rose).

\section{Designing Assessments}

Kenanga, a novice teacher also thinks that she would like to receive more trainings on assessments, especially in items building. This is so as teachers are the ones who are in charge of producing exam papers for internal examination such as quiz and standardized test. For most of the times, she will find samples of questions from workbooks and other reference books, but this could be irrelevant because students will also have accessed to them. She claimed that regular items building courses are important to give teachers continuous exposure and knowledge in designing effective examination questions.

A training that I would like to go to is the one on designing exam questions and assessments. To me, what is considered as good question and how does it test our students real ability and comprehension. I ask around and no one seems to know. There must be someone who knows and perhaps can teach us how to do it (Kenanga).

\section{Stress Management}

Melati perceived the teaching training she has received are sufficient as she believes that handson experiences are more vital for teachers. Nonetheless, she is eager to receive courses related to stress management. This is so because sometimes she feels overwhelmed with all the works given other than teaching. The school system that also focuses on the ranking is somewhat burdening as teachers need to accentuate both on academic, co-curricular activities and other clerical works needed. She believes that stress management courses will be helpful for teachers to alleviate the pressure imposed on them. Teachers also will have knowledge on how to work under pressure and manage their tasks efficiently.

Working as a teacher is stressful. So many things to do, so many people to answer to.the work does not end at school. It is worse if you have other roles as well. The management, I mean, the school, the upper management does not care or perhaps they are not aware. Is there any stress management courses? I only heard they have them in private, international big companies. But for teachers? I think we need one especially now (Melati).

Melur in the focus group discussion mentioned that with the new norms, there seems to be more challenges and tasks that need to be done. The demands of teaching online are challenging and they require a lot of time and effort. She mentions that this has interrupts her own personal time and she often has to work until late at night to prepare for her classes. She admits that she struggles, and this has taken its toil on her mental and physical health. 


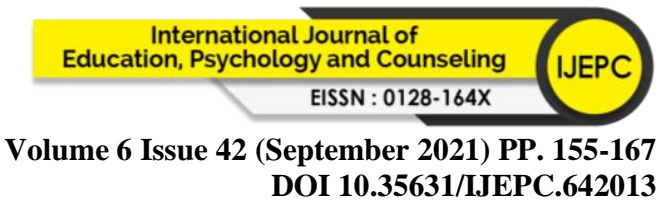

Online class, online meeting, everything online. Ok, materials need to change to online. Assessments too but sometimes students can't access so now you have to find solutions. Alternatives to help these students. So, you ended up doing 2 things for one. It is tiring. I am tired but what can we do. The head teacher should do something about this. Find a course, invite someone to help us who are burnout. I sleep less and less hours now just to do the schoolwork. A lot of preparation.

These are few of the common laments that English language teachers voiced out in both the interviews and the focus group discussions. All of these indicate that they need relevant courses in not only propelling them in their career growth, but most importantly to help them on a day to day basis, dealing with the demands of the new norms.

In conclusion, all the participants agreed that teachers' training is one of the important aspects in their professional development. The trainings offered must be holistic and conducted thoroughly.

\section{Discussions and Conclusion}

For professional development to provide teachers with new skills and enhance their current skills, it needs to be applicable to their needs with teacher leadership and input. Fullan (2007) suggested that teacher leadership and motivation have declined and have reduced the quality and meaningfulness of professional development. Although students rely heavily on teachers to positively motivate them (Sulistiyarini \& Sukardi, 2016), but it is not easy as teachers are often burnt out and demotivated themselves. Respondents revealed that by incorporating teacher needs in terms of teacher training, teachers are able to engage in personalized dialog to improve their professional practices and student achievement. Alignment is very important to ensure that professional development is effective in accomplishing both personal objectives and school-based objectives. According to Stewart (2014), focused and aligned professional development through teachers' training increases learning. Some participants explained that due to the alignment of professional development with their content area, their instructional practices had improved with student-focused and data-driven instruction. However, most participants reported a lack of alignment. Teachers need time and support to implement the practices learned in professional development. If proper resources are not available, then professional development may not be fully implemented well. Professional development needs to focus on data-analysis and developing high stakes classroom assessments as well as teachers' mental well-being as an educator.

The present study indicates that MARA English school teachers have positive perceptions of the teaching profession and for that reason they believe teacher training is essential for their professional development. Most of them agreed that the teacher training they have received is inadequate and they would like to receive more courses in terms of tools familiarisation, teacher proficiency level, materials preparation, stress management, and lesson development. The list of courses needed by teachers vary because very year the courses offered are different and some of them only select a representative from respective school so that they can conduct a inhouse training when they return. The study provides clear evidence of the possible intercorrelations among the school environment, technology literacy and teaching language skill (Sadeghi \& Nikou, 2012; Tran,2015; Arficho, 2018). Based on these findings, Educators and administrators may recognize the detrimental factors to teaching-learning and find effective solutions to improve the situation. This study also used teacher's age and gender, and type of Copyright (C) GLOBAL ACADEMIC EXCELLENCE (M) SDN BHD - All rights reserved 


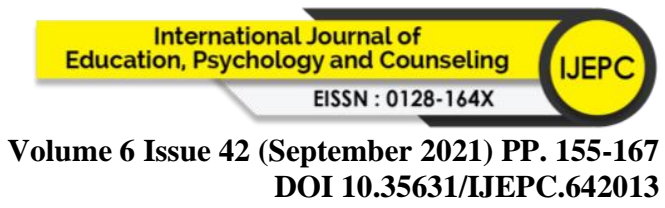

school being public or private as the independent variables. Future studies should further consider teacher's teaching experience, subject taught, and school size and school location. Related research considered these factors significant in measuring the effectiveness of professional development.

\section{References}

Braun, V and Clarke, V. (2013) Successful Qualitative Research: a practical guide for beginners. London: Sage Publications Ltd.

Creswell, J.W. (2009). Research design: qualitative, quantitative, and mixed method approaches. 3rd ed. Thousand Oaks, CA: Sage. Publications Ltd.

Creswell, J. (2013). Qualitative inquiry and research design: choosing among five approaches. Thousand Oaks, CA: Sage Publications Ltd.

Creswell, J. (2015). 30 essential skills for the qualitative researcher. Los Angeles, CA: Sage.

Creswell, J. W., \& Creswell, J. D. (2018). Research design: qualitative, quantitative, and mixed methods approaches (5th ed.). Thousand Oaks, CA: SAGE Publications, Inc.

Day, C. (1999). Developing teachers: The challenges of lifelong learning. London: Falmer Press.

Foo Lung Choe \& Bhatti, N. (2019). Malaysian School English Language Teachers' Perceptions on Teaching and Learning. International Journal of Applied Linguistics \& English Literature, 8 (4), 11-16.

Fullan, M. (2007). The new meaning of educational change. New York, NY: Teachers College Press.

Guskey, T. R. (2002). Professional development and teacher change. Teachers and teaching, 8(3), 381-391.

Had, M. Z. C., \& Rashid, R. A. (2019). A Review of Digital Skills of Malaysian English Language Teachers. International Journal of Emerging Technologies in Learning, 14(2).

Hargreaves, A. and Fullan, M. (2012). Professional Capital: Transforming Teaching in Every School. USA: Teachers College Press

Ismail, S. N., Rahman, F. A., \& Yaacob, A. (2020). School Climate and Academic Performance. In Oxford Research Encyclopedia of Education.

Kepol, N. (2017). Quality Malaysian English Language Teachers: Examining A Policy Strategy. Malaysian Journal of Learning and Instruction. 14 (1), 187-209.

Laine, S., Begrstock-Sherrat, E., and Lasagna, M. (2011). Improving Teacher Quality. Josseybass, San Fransisco: Wiley.

Learning Forward. (2011). Standards for professional learning. Oxford, OH.

Lortie, D. C. (2020). Schoolteacher: A sociological study. University of Chicago Press.

OECD (2012). Equity and quality in education. supporting disadvantaged students and schools. paris. http://www.oecd.org/education/school/49603597.pdf.

Polly, D., McGee, J., Wang, C., Martin, C., Lambert, R., Pugalee, D. (2015). Linking professional development, teacher outcomes, and student achievement: The case of a learner-centered mathematics program for elementary school teachers. International Journal of Educational Research, 72, 26-3.

Pring, R. (2011). Trusting teachers: Learning from a bit of history. Education Review, 23(2).

Sadeghi, K., \& Nikou, S., B. (2012). Perceptions of Iranian high school EFL teachers and students toward teaching and learning reading skill. 3L: The Southeast Asian Journal of English Language Studies,18(4),167-180.

Stewart, C. (2014). Transforming professional development to professional learning. Journal of Adult Education, 43 (1), 28-33 Available from: 
http://ezp.waldenulibrary.org/login?url=http://search.ebscohost.com/login.aspx?direct $=$ true $\& \mathrm{db}=$ eric $\& \mathrm{AN}=\mathrm{EJ} 1047338 \&$ site $=$ eds-live $\&$ scope $=$ site.

Sugita McEown, M., \& Takeuchi, O. (2014). Motivational strategies in EFL classrooms: how do teachers impact students' motivation? Innovation in Language Learning and Teaching, 8(1), 20-38.

Sulistiyarini, D., \& Sukardi, S. (2016). The Influence Of Motivation, Learning Styles, Teacher Leadership, And Teaching Intensity On Students'leaning Outcomes. Jurnal Pendidikan Teknologi dan Kejuruan, 23(2), 136-143.

Tsegay, S. M., \& Ashraf, M. A. (2015). The influence of senior secondary school teachers on students' achievement in Gao-Kao. International journal of Research studies in Education, 4(4), 67-76. 